\title{
Hubungan Keterampilan Sosial dan Kepercayaan Diri Peserta Didik Kelas VIII di SMPSN 8 Yogyakarta
}

\author{
Tri Dewantari' ${ }^{1}$, Hardiyansyah Masya ${ }^{2}$ \\ ${ }^{1}$ Universitas Negeri Yogyakarta, ${ }^{2}$ Universitas Islam Negeri Raden Intan Lampung \\ dewantaritri@gmail.com
}

Submitted: 05-10-2018, Revised: 24-11-2018, Accepted: 24-12-2018

\begin{abstract}
Social skills and self-confidence are two things that are interrelated. In junior high school students who have social skills and confidence is very important for learners. The research design uses correlation design. The researchers collected data on social enlightenment and self-confidence using the scale of skills and social beliefs that had been tested for their validity and reliablity. The subjects used in this study were 158 students at SMPN 8 Yogyakarta taken through random sampling technique from the population as much. The results of data processing showed that most of the students of grade VIII SMPN 8 Yogyakarta had high social and confidence skills, and data analysis showed that there was a relationship between social skills and students' self-confidence. The results of this study are useful for counselors as an illustration of the conditions of social skills and selfconfidence that can be taken into consideration in preparing a counseling and counseling service program in junior high schools.
\end{abstract}

Keywords: Social Skills, Self Confidence

\begin{abstract}
Abstrak: Keterampilan sosial dan kepercayaan diri merupakan dua hal yang berkaitan. Pada peserta didik tingkat sekolah menengah pertama (SMP) memiliki keterampilan sosial dan kepercayaan diri merupakan hal yang penting dimiliki peserta didik. Penelitian ini bertujuan untuk melihat gambaran hubungan keterampilan sosial dan kepercayaan diri peserta didik. Desain penelitian menggunakan rancangan korelasi. Peneliti mengumpulkan data keterampian sosial dan kepercayaan diri dengan menggunakan skala keterampilan sosial dan kepercayaan diri yang sudah diuji validitas dan reliablitasnya. Subyek yang digunakan pada penelitian ini yaitu 158 peserta didik di SMPN 8 Yogyakarta yang diambil melalui teknik random sampling dari populasi sebanyak . Adapun hasil pengolahan data menunjukkan sebagian besar siswa kelas VIII SMPN 8 Yogyakarta memiliki keterampilan sosial dan kepercayaan diri yang tinggi, dan analisis data memnunjukkan bahwa terdapat hubungan antara keterampilan sosial dan kepercayaan diri peserta didik. Hasil penelitian ini bermanfaat bagi konselor sebagai gambaran tentang kondisi keterampilan sosial dan kepercayaan diri yang dapat dijadikan bahan pertimbangan di dalam menyusun program layanan bimbingan dan konseling di sekolah menengah pertama.
\end{abstract}

Kata Kunci: Keterampilan Sosial; Kepercayaan Diri

\section{Pendahuluan}

Pendidikan merupakan suatu hal yang penting dan tidak dapat dipisahkan dari kehidupan manusia. Setiap manusia memerlukan pendidikan untuk dapat meningkatkan kualitas hidupnya. Menurut SISDIKNAS Nomor 20 Tahun 2003 (2011:3), "pendidikan adalah usaha sadar dan terencana untuk mewujudkan suasana belajar dan proses pembelajaran agar peserta didik secara aktif mengembangkan potensi dirinya untuk memiliki kekuatan spiritual keagamaan, pengendalian diri, kepribadian, kecerdasan, akhlak mulia, serta keterampilan yang diperlukan dirinya, masyarakat, bangsa dan negara".

Untuk mewujudkan tujuan-tujuan di dalam belajar dapat dilakukan dengan melalui proses belajar mengajar yang terjadi di sekolah. Dengan adanya pendidikan, peserta didik dapat dengan aktif mengembangkan potensi yang ada pada dirinya sesuai dengan fase perkembangannya. Selain itu, menurut Erikson (Santrock, 2002:43) salah satu tugas perkembangan masa remaja yaitu dapat mengetahui identitas dirinya, memiliki cita-cita dalam kehidupan dan mulai mengambil peran dalam aktivitasnya di lingkungan sosial. Untuk mewujudkan hal tersebut maka remaja perlu memiliki 
keterampilan sosial dan kepercayaan diri yang baik, sehingga remaja dapat mengetahui identitas diri, kekurangan dan kelebihan dirinya serta dapat mengambil peran di lingkungan sekitarnya.

Namun pada kenyataannya yang terjadi, masih banyak perilaku peserta didik yang tidak sesuai dengan kenyataan. Adapun masalah yang terjadi pada peserta didik tingkat SMP yaitu peserta didik menghindari berinteraksi dengan guru, menghindari saat berinteraksi dengan teman yang tidak dekat, berteman hanya pada salah satu teman dekat saja, lebih menyenangi sendiri. Perilaku bermasalah tersebut terlihat pada saat pembelajaran berlangsung atau pada saat jam istirahat.

Kepercayaan diri merupakan suatu modal utama yang dimiliki oleh peserta didik di dalam mengkesplor dirinya baik di dalam lingkungan sosial maupun di dalam prestasi belajar. Kurangnya kepercayaan diri dapat menyebabkan rasa tidak nyaman dan dapat menimbulkan banyak masalah. Rendahnya rasa percaya diri bisa menyebabkan depresi, bunuh diri, anoreksia nervosa, delinkuensi, dan masalah penyesuaian diri lainnya. Ketika tingkat percaya diri yang rendah berhubungan dengan proses belajar seperti prestasi rendah, atau kehidupan keluarga yang sulit, atau dengan kejadian-kejadian yang membuat tertekan, masalah yang muncul dapat menjadi lebih meningkat (Santrock, 2003). Dengan memiliki kepercayaan diri peserta didik peserta didik mampu mengembangkan bakat, minat dan potensi yang ada pada dirinya (Komara, 2016). Selain itu Menurut Komara (2016) semakin tinggi kepercayaan diri dan prestasi belajar maka perencanaan karir semakin tinggi dan sebaliknya apabila kepercayaan diri dan prestasi belajar rendah maka perencanaan karir akan semakin rendah. Selain itu berdasarkan penelitian Sudardjo dan Purnamaningsih (2003) semakin tinggi kepercayaan diri maka semakin rendah kecemasan komunikasi interpersonal. Berdasarkan pendapat tersebut kepercayaan diri berpengaruh terhadap prestasi belajar maupun komunikasi interpersonal peserta didik dengan lingkungan. Dengan memiliki kepercayaan diri peserta didik dapat memiliki keyakinan terhadap segala hal yang dilakukannya, sehingga peserta didik dapat berkembang secara optimal dalam kehidupannya. Hal ini sesuai dengan pendapat Azmandian (2010: 80) yang menyatakan bahwa, rasa percaya diri adalah prasyarat untuk hubungan yang indah dan produktif dan rasa percaya diri adalah akar pertumbuhan dan keunggulan manusia.

Hal tersebut diperkuat oleh penelitian Hasanah, Supriyono, Herani, dan Lestari (2010) yang menyatakan bahwa di dalam proses belajar mengajar diperlukan komunikasi agar proses belajar mengajar berjalan dengan efektif. Untuk dapat mewujudkan komunikasi yang efektif maka diperlukan kepercayaan diri. Hal ini senada dengan pendapat Makinde dan Jonathan (2013) yang menyatakan bahwa dengan memiliki rasa percaya diri akan membantu peserta didik dalam menangani kritik, menunjukkan kasih sayang, bersikap optimis dan bersikap tegas, hal tersebut akan membantu peserta didik dalam berinteraksi dengan lingkungan sekitar. Indikasi individu yang memiliki kepercayaan diri menurut Sudardjo dan Purnamaningsih (2003) yaitu memiliki keyakinan akan kemampuan dirinya.

Ciri-ciri individu yang memiliki kepercayaan diri menurut Serarslan dan Dirik (2017) diperlihatkan dengan adanya perilaku merasa percaya diri, memiliki keinginan untuk sukses dan mencapai tujuan, tidak mudah menyerah, bertanggung jawab, terbuka terhadap pengalaman dan mudah bergaul dalam hubungan mereka. Adapun faktor yang mempengaruhi timbulnya kepercayaan diri peserta didik menurut Hakim (2004:121) Adapun faktor yang dapat mempengaruhi timbulnya kepercayaan diri yaitu faktor lingkungan keluarga dalam hal ini seperti motivasi dalam keluarga sangat berpengaruh terhadap kepercayaan diri peserta didik. Faktor pendidikan formal dalam hal ini seperti di sekolah penerimaan teman-teman dan lingkungan sekolah terhadap peserta didik dapat mempengaruhi timbulnya rasa percaya diri peserta didik. Faktor pendidikan non formal seperti kursus membuat peserta didik memiliki keahlian tertentu sehingga akan membuat peserta didik lebih percaya diri.

Di dalam Penelitian Lebedour (Asmiana dalam Musslifah, 2008, Kushartanti, 2009) terhadap 25 universitas yang ada di 5 negara (United State, Nederland, Israel, Palestine, dan Taiwan), menyebutkan bahwa jenis kelamin dan kebudayaan sangat mempengaruhi tingkat percaya diri individu. Secara spesifik penelitian ini menyebutkan bahwa perbedaan jenis kelamin akan membawa perbedaan pada rasa percaya diri individu. Selanjutnya, penelitian Jhonson (Asmiana dalam Musslifah, 2008) pada 363 pelajar di 3 sekolah dasar umum dengan 174 wanita dan 189 pria menunjukkan bahwa perbedaan jenis kelamin mengakibatkan perbedaan rasa percaya diri pada pelajar, dan hal tersebut berkorelasi terhadap perilaku menyonteknya.

Adapun faktor penyebab terjadinya keterampilan sosial yaitu menurut Cartledge dan Milburn (1995: 4) yaitu kemampuan untuk berinteraksi dengan orang lain dalam konteks sosial tertentu dengan cara tertentu yang secara sosial dapat diterima atau dihargai pada saat yang sama dan secara pribadi 
menguntungkan atau bermanfaat kepada orang lain. Selain itu, keterampilan sosial menurut Matson (2009: 6) yaitu individu mampu memilih dan melakukan perilaku yang tepat sesuai dengan tuntutan lingkungannya. Senada dengan hal tersebut, Samanci (dalam Matson, 2009: 41) juga menyatakan individu yang memiliki keterampilan sosial mampu berkomunikasi, memecahkan masalah, membuat keputusan dan mampu mengekspresikan dirinya.

Selain kepercayaan diri, keterampilan sosial yang dimiliki peserta didik akan berdampak pada hasil belajar yang diperolehnya. Hal ini senada menurut pendapat Misti (2010:7) semakin baik kemampuan sosial peserta didik maka cenderung semakin baik pula hasil belajar yang diperoleh. Adapun ciri-ciri peserta didik yang memiliki keterampilan sosial yang baik dapat ditunjukkan dengan perilaku keterampilan sosial yang baik menurut Caldarella dan Merrel (dalam Matson, 2009: 4), yaitu menunjukkan perilaku seperti memiliki hubungan baik dengan teman sebaya, memiliki keterampilan dalam pengelolaan diri, memiliki keterampilan akademik, patuh dalam perilaku sosial serta dapat berperilaku asertif.

Untuk dapat memiliki keterampilan sosial maka diperlukan kepercayaan diri. Senada dengan hal tersebut menurut Samanci (Matson, 2009:11) yang menyatakan bahwa faktor-faktor terjadi keterampilan sosial yaitu keluarga, sekolah, lingkungan masyarakat, dan karakteristik individu. Salah satu karakteristik individu yang berpengaruh terhadap perkembangan keterampilan sosial yaitu keterampilan berbahasa, keterampilan komunikasi dan kepercayaan diri. Berdasarkan pendapat tersebut kepercayaan diri merupakan faktor yang dibutuhkan di dalam keterampilan sosial, karena dengan memiliki kepercayaan diri peserta didik akan memiliki keyakinan terhadap sesuatu yang dilakukannya baik di dalam interaksinya dengan orang lain maupun hubungan dengan teman sebaya, hal ini menunjukkan bahwa keterampilan sosial dan kepercayaan diri merupakan dua hal yang penting dimiliki oleh peserta didik.

Menurut goodstadt dan Kipnir (Bunker dkk, 1983) orang yang memiliki kepercayaan diri tinggi umumnya dapat lebih mudah terlibat secara pribadi dengan orang lain dan lebih berhasil dalam hubungan interpersonal (Goodstadt \& Kipnir, dalam Bunker dkk, 1983). Sudut pandang seseorang di dalam menghadapi orang lain dipengaruhi bagaimana seseorang tersebut memandang dirinya sendiri. Respon-respon interpersonal seseorang sering merupakan refleksi dari kognisinya terhadap diri sendiri (Krech dalam Purnamaningsih, 2003).

Berdasar latar belakang tersebut, di dalam penelitian ini tujuan utamanya yaitu untuk mengetahui hubungan antara keterampilan sosial dan kepercayaan diri peserta didik kelas VIII di SMPN 8 Yogyakarta.

\section{Metode Penelitian}

Penelitian ini dilakukan di SMPN 8 Yogyakarta, dengan jenis penelitian yaitu penelitian korelasi. Penelitian korelasi yaitu bertujuan untuk menentukan kecenderungan atau pola untuk dua variable atau lebih (Creswell, 2015:664). Pada penelitian ini melihat ada atau tidaknya hubungan antar tiap variable.

Populasi dalam penelitian ini adalah peserta didik kelas VIII SMPN 8 Yogyakarta yang berjumlah 158 peserta didik. Adapun instrumen yang digunakan di dalam penelitian ini yaitu dengan menggunakan skala keterampilan sosial dan kepercayaan diri. Teknik pengumpulan data yang digunakan pada penelitian ini adalah dengan menggunakan skala keterampilan sosial dan kepercayaan diri, yang digunakan untuk mengukur tingkat keterampilan sosial dan kepercayaan diri peserta didik.

Analisis data yang digunakan dalam penelitian ini adalah analisis kuantitatif. Analisis korelasi digunakan untuk menguji hipotesis adanya hubungan antara keterampilan komunikasi interpersonal dan kepercayaan diri siswa. Setelah data diperoleh, maka langkah selanjutnya peneliti mengolah data untuk memperoleh kesimpulan akhir dalam penelitian. Dalam penelitian ini analisis data disajikan dengan penyajian data melalui tabel dengan menggunakan bantuan komputer SPSS (Statistical Package for Social Science) yang menggunakan korelasi product moment yang dikemukakan oleh Pearson. Hasil korelasi jika nilai signifikansi kurang dari atau sama dengan 0,05 maka dapat dikatakan signifikan. Sebaliknya jika signifikansi lebih dari 0,05 maka dapat dikatakan tidak signifikan. 


\section{Hasil dan Pembahasan}

Berdasarkan hasil analisis keterampilan sosial peserta didik di SMPN 8 Yogyakarta sebagian besar berada pada kategori tinggi dan tidak terdapat peserta didik yang berada pada kategori rendah.

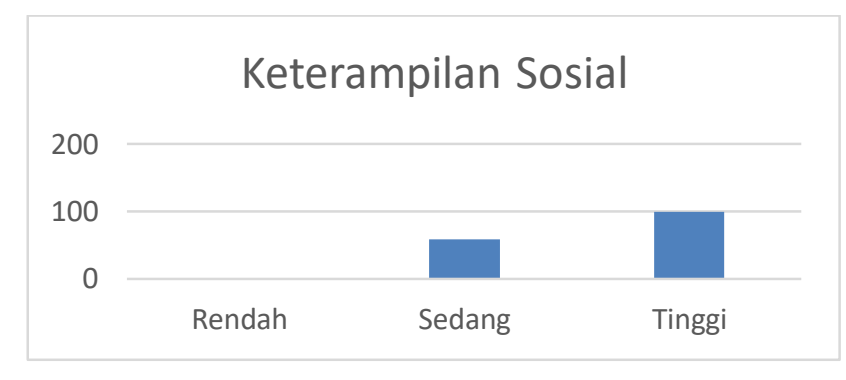

\section{Grafik 1.}

Data Keterampilan Sosial

Berdasarkan grafik 1. Terlihat bahwa dari 158 peserta didik kelas VIII di SMPN 8 Yogyakarta di dapat sebayak 100 peserta didik berada pada kategori tinggi, 58 peserta didik berada pada kategori sedang, dan tidak terdapat peserta didik yang berada pada kategori rendah. Hal tersebut juga terjadi dengan analisis kepercayaan diri. Sebagian besar sedangkan pada analisis data kepercayaan diri di dapat data 99 peserta didik berada pada kategori tinggi, 59 peserta didik berada pada kategori sedang, dan tidak terdapat peserta didik yang berada pada kategori rendah.

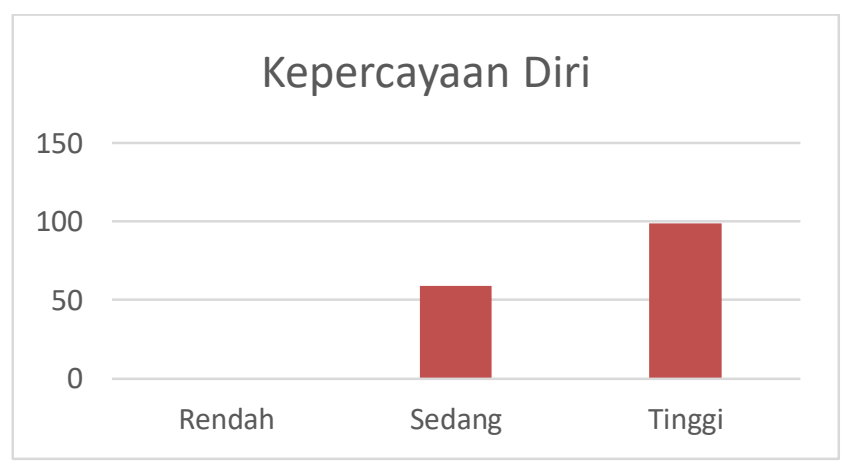

Grafik 2.

Data Kepercayaan Diri

Berdasarkan analisis korelasi dapat diketahui antara keterampilan sosial dengan kepercayaan diri memiliki korelasi yang signifikan yaitu dikarenakan nilai signifikansi lebih besar dari $0,05(0.000 \geq 0,05)$ dengan $\mathrm{df}(\mathrm{N}-2)=158-2=156$. Hal tersebut membuktikan bahwa terdapat hubungan yang signifikan antara keterampilan sosial dan kepercayaan diri peserta didik. 


\begin{tabular}{|ll|r|r|}
\hline \multicolumn{2}{|c|}{ Correlations } \\
\hline KS & Pearson Correlation & \multicolumn{1}{c|}{ KD } \\
& Sig. (2-tailed) & 1 & $.998^{*}$ \\
& $\mathrm{~N}$ & & .000 \\
& & 158 & 158 \\
\hline KD $\quad$ Pearson Correlation & $.998^{* *}$ & 1 \\
& Sig. (2-tailed) & .000 & \\
& N & 158 & 158 \\
\hline
\end{tabular}

Analisis terhadap data penelitian menghasilkan koefisien korelasi sebesar 0,998 dengan $\mathrm{p}<0,00$ yang berarti ada hubungan yang signifikan antara kepercayaan diri dengan keterampilan sosial. Berarti semakin tinggi kepercayaan diri, maka semakin tinggi keterampilan sosial, begitu pula sebaliknya.

\section{Simpulan dan Saran}

Berdasarkan pada tujuan, hasil pembahasan penelitian, maka dapat disimpulkan pada penelitian ini yaitu gambaran keterampilan sosial dan kepercayaan diri pada peserta didik yaitu $63 \%$ peserta didik memiliki keterampilan sosial pada kategori tinggi dan $37 \%$ peserta didik berada pada kategori sedang. Sehingga dapat disimpulkan bahwa sebagian besar siswa kelas VIII SMPN 8 Yogyakarta memliki keterampilan sosial dan kepercayaan diri yang tinggi, dan terdapat hubungan yang signifikan antara keterampilan sosial dan kepercayaan diri peserta didik di SMPN 8 Yogyakarta. Kekurangan di dalam penelitian ini yaitu karena keterbatasan waktu penelitian hanya dilakukan pada kelas VIII, untuk peneliti selanjutnya penelitian dapat dilakukan pada kelas tingkat-tingkat kelas yang lainnya.

Berdasarkan hasil penelitian, peneliti memberikan saran-saran kepada peneliti lain yang akan melakukan penelitian yang serupa yaitu hendaknya melakukan penelitian tentang keterampilan sosial dan kepercayaan diri pada peserta didik hendaknya dapat memberikan solusi dengan pemberian treathment untuk meningkatkan keterampilan sosial dan kepercayaan diri peserta didik sebagai tindak lanjut.

\section{Daftar Pustaka}

Azmandian, A. (2010). Think Yourself Successful Rewire Your Mind, Become Confident, and Achieve Your Goals. United States: The McGraw-Hill Companies, Inc.

Cardarella dan Merrel. (1995). Common Dimensions of Social Skills of Children and Adolescents: A Review and Analysis of the Literature. Logan: Utah State University.

Hasanah, N., Supriyono, Y., \& Lestari, S. Peningkatan Kepercayaan Diri Mahasiswa Melalui Pelatihan Asertivitas. Dosen Program Psikologi, Universitas Brawijaya. http://interaktif.ub.ac.id/index.php/interaktif/article/view/115.

Keliat, A.B., Tololiut, A.T., Daulima, C.H.N., \& Erawati, E. (2015). Effectiveness Assertive Training of Bullying Prevention among Adolescents in West Java Indonesia. International Journal of Nursing. http://dx.doi.org/10.15640/ijn.v2n1a14. 
Makinde, O.B., \& Akinteye, J.A. (2014). Effects of Mentoring and Assertiveness Training on Adolescents' Self-Esteem in Lagos State Secondary Schools. International Journal of Social Science Studies. http://ijsss.redfame.com.

Matson, L. Johnny. (2009). Social Behavior and Skills in Children. USA: Springer

Saraslen, M dan Dirik, K (2017). Assesment of Self-Confidence Levels in Adolcents in Terms of Certain Variables. RA Jorunal of Applied Research. http://www.rajournals.in/images/ijararticle/v3-i1/1rajar.pdf

Sudardjo, S \& Purnamaningsih, E.R. (2003). Kepercayaan Diri Dan Kecemasan Komunikasi Interpersonal Pada Mahasiswa. Jurnal Psikologi Universitas Gajah Mada. https://doi.org/10.22146/jpsi.7025.

Suntrock, J.W. (2002). Life-Span Development (Perkembangan Masa Hidup). Jakarta: PT Erlangga. 